\title{
Zpráva z konference European Survey Research Association 2007 v Praze
}

Ve dnech 25. - 29. 6. 2007 se v Praze na Vysoké škole ekonomické (VŠE) konala mezinárodní konference Evropské asociace pro dotazníková šetření - European Survey Research Association (ESRA). Garanci nad konferencí převzal vedle zmíněných institucí také Český statistický úřad (ČSÚ).

ESRA je relativně novou výzkumnou asociací sdružující odborníky především z Evropy v oblasti dotazníkových šetření, zejména statistiky, a odborníky zabývající se metodologií a statistickým zpracováním dat v linii kvantitativního empirického výzkumu. Předsedou asociace je prof. Willem Saris ze Španělska, podílející se na mezinárodním sociálním výzkumu European Social Survey (ESS). Konference v Praze je druhou konferencí asociace, první konference se konala $v$ Barceloně v roce 2005 , konference se koná vždy jednou za dva roky. Prozatím je velmi nízký členský poplatek v organizaci (10 Euro), který se však od prríštího roku asi o něco zvýší. Také konferenční poplatek je dostupný pro účastníky z Česka - kolem 3000 Kč.

Asociace vydává časopis Survey research methods (SRM), kde je prozatím vzhledem k ostatním prestižním časopisům ve světě relativně výhodný poměr nepřijatých článků (50\%). Časopis zveřejňuje jak články prezentující nové statistické, metodologické postupy, tak výzkumné zprávy aplikující všeobecně rozšiřené postupy.

Mezi pozvané přednášející panelových přednášek byli Jan van Deth z univerzity v Mannheimu, která patří mezi nejlepší univerzity v oblasti výzkumu v sociálních vědách $v$ Německu, který diskutoval světově rozšířené a aktuální téma měření sociálního kapitálu. Dalším hlavním přednášejícím byl Albert Satorra ze Španělska, který hovořil o specifických problémech spojených s testováním strukturních modelů (structural equation models), které jsou v současnosti velmi často používány zejména v psychologii a dalších sociálních vědách. Tématem webových průzkumů, jejich výhodami a nevýhodami se zabýval Vasja Vehovar z univerzity v Lublaně. Na konferenci se prezentoval Český statistický úrad jako moderní instituce otvírající se výzkumu a uživatelům statistických dat a nakladatelství SAGE s nově vycházející knihou Measuring Attitudes Cross-Nationally: Lessons from the European Social Survey (Mezinárodní měření postojủ: Lekce z Evropského sociálního výzkumu), jejímiž autory byly nejvýznamnější představitelé ESRA. Kniha reaguje na významný výzkum European Social Survey (ESS), který je světově známý díky metodologickému propracování na špičkové úrovni.

Asi 400 účastníků, z toho 300 prezentujících, se účastnilo konference v několika paralelních sekcích v nově postavené reprezentativní budově VŠE. Z konference je dostupný přehled abstraktů článků na $\mathrm{CD}$ a na webových stránkách. První sekce se zabývala komparativním výzkumem - vytvářením indikátorů pro zjištování postojů, výběrem vzorku pro mezinárodní výzkumy, vícerozměrnými analýzami, koncepty měření kvality v ESS, komparativním dotazníkovým designem, sběrem 
dat a harmonizací dotazníkových dat. Druhá sekce se zabývala kvalitou položek dotazníku - překladem a adaptací dotazníků, interview, kvalitou dotazníkových šetření, zvyšováním validity, kódováním, softwarem a kvalitou indikátorů. Třetí sekce se týkala výzkumu sociálního, politického a administrativního chování - měření kvality demokracie pomocí dotazníků, analýzami postojů vůči migraci, lidskými hodnotami, výzkumem emoční inteligence, měřením kvality služeb, důvěry a Evropským výzkumem hodnot (European Values Study). Sekce „analýza dat“ zahrnovala problémy jako testování strukturálních modelů (SEM), vícerozměrné a marginální modely, analýzy postojů, modely analýzy subjektivních dat a indikátorů, analýzy strategií mezinárodních výzkumů, strategie pro chybějící data, měření př́ijmu atd. Pátá sekce se týkala výběru vzorku, sběru dat a chybějících odpovědí, návratností dotazníků a chybami měření. Šestá sekce diskutovala téma způsobu sběru dat a zlepšování kvality dat - kombinování různých modelů sběru dat, klasifikace dat, sběr dat, webový sběr dat, používání paradat pro evaluaci dotazníkových šetření a zvyšování kvality, hodnocení kvality mezinárodních šetření, redukci, detekci a adjustaci chyb z důvodu chybějících dat, pravděpodobnost, telefonní sběr dat a jeho implikace pro kvalitu dotazování, odhady. Poslední dvě sekce se zabývaly specifickými tématy, příspěvky byly z různých oblastí a týkaly se měření dané oblasti a metodologickými postupy. Jednalo se např. o problematické skupiny respondentů, etické otázky, Výzkum zdraví v Evropě (Health Survey in Europe), měření sítě vztahů (network) aj.

Konferenci předcházely dva metodologické půldenní kurzy. Peter Lynn z University of Essex se zabýval testováním hypotéz využívajících komplexních dotazníkových dat. Willem Saris (ESADE, Španělsko) přednášel o vytváření dotazníkových položek za použití lingvistických informací (rozlišování intuitivních a postulovaných konceptů, o objektivních a subjektivních proměnných, přímých a nepřímých otázkách, rozlišení mezi charakterem položek zaměřených na evaluaci, určení významnosti pro respondenta, zjištování pocitů a kognitivních závěrů). Dále se zabýval specifickými požadavky kladenými na dotazníkové otázky (specifikace výzkumné oblasti a časového rámce otázky, sociální žádoucnost, předchozí obeznámenost s tématem), specifiky baterií otázek a dalšími problémy při tvorbě položek (dvojitými otázkami), počtem kategorií škály a jejich reliabilitou, výběrem modelu sběru dat atd. W. Saris chápal vytváření položek jako sérii mnoha různých rozhodnutí, důležité je vždy zvažovat, zda tato rozhodnutí o podobě položek a dalších aspektech s nimi souvisejícími jdou směrem ke kvalitě dotazníku. Ukazoval také různé důsledky daných rozhodnutí (velikost škály, kategorie aj.). Dále se zabýval náhodnou a systematickou chybou a zdůrazňoval nutnost korekce chyb, aby výsledky byly co nejpřesnější a nedocházelo k jejich zkreslení. Popisoval MTMM experimenty a korekci chyb. Zdůrazňoval, že není možné srovnávat korelace/regrese metod nebo zemí bez korekce chyb měření. Zabýval se také predikcí kvality měření/otázek pomocí programu SQP (Survey quality prediction) a metaanalýzou MTMM experimentů. Dále také kvalitou složených skóre, faktorovými modely a požadavky na interkulturní (cross-cultural) komparaci jako jsou ekvivalence, invariance, srovnáváním průměrů a vztahů jedné otázky, složených skóre a latentních proměnných, 
jejich výhodami a omezeními. Doporučoval pracovat s latentními proměnnými, vyhnout se složeným skórům a srovnáváním na základě jedné položky.

Konferenci Ize hodnotit jako velmi prínosnou z hlediska obsahu i organizace a je škoda, že se jí za Českou republiku zúčastnilo minimum účastníků.

Odkazy

Stránky konference: http://esra2007.vse.cz/home/

ESRA stránky: http://esra.sqp.nl/esra/home/

Časopis SRM: $\quad$ http://surveymethods.org

Kateřina Vlčková 